\title{
A CRIMINALIZAÇÃO MIDIÁTICA DO MOVIMENTO SOCIAL DE LUTA PELA MORADIA DIGNA
}

\author{
HELIO JORGE REGIS ALMEIDA ${ }^{1}$ \\ JORGE LUIZ OLIVEIRA DOS SANTOS² \\ BRUNO SOEIRO VIEIRA ${ }^{3}$
}

\section{Resumo}

Busca o artigo identificar qual o conteúdo discursivo dominante emitido pela mídia impressa brasileira sobre o movimento social pela moradia urbana, a partir da tragédia do caso do desabamento do edifício Wilton Paes de Almeida, em maio de 2018 em São Paulo. Trata-se de uma pesquisa quali-quantitativa que utiliza a técnica da análise do conteúdo, por meio da seleção das matérias jornalísticas e editoriais dos jornais impressos (versão digital) mais vendidos do Brasil, no entretempo de 2 a 31 de maio de 2018. Foi adotado como critério metodológico de seleção dos jornais o levantamento mais recente do Instituto Verificador de Circulação (IVC), órgão da Associação Nacional de Jornais (ANJ). O método de análise de dados (palavras-chave) coletou registros dados quantitativos por intermédio do software Search my files e posterior análise qualitativa do conjunto dos registros encontrados. Constatou-se clara tendência de utilização pela imprensa de palavras que expressam uma ideologia e um conteúdo discursivo que representa preconceito, estigmatização e imputação de condutas criminosas ao movimento social pela moradia urbana. Outrosssim, esta pesquisa é relevante por evidenciar um

\footnotetext{
${ }^{1}$ Doutor em Ciências Sociais (Antropologia) pelo Programa de Pós-Graduação em Ciências Sociais (PPGCS) da Universidade Federal do Pará (UFPA - 2011). Mestre em Antropologia pelo Departamento de Antropologia (DEAN) da Universidade Federal do Pará (UFPA - 2004). Bacharel em Ciências Sociais pela Universidade da Amazônia (UNAMA - 2001). Atualmente exerce atividade docente, como Professor Titular Pós-Stricto Senso I, na Universidade da Amazônia (UNAMA). Tem experiência na área de Antropologia, com ênfase em Etnografia, atuando principalmente nos seguintes temas: cultura, consumo, festas populares, direito, violência, família, sexualidade e gênero. Universidade da Amazônia - UNAMA. Brasil. E-mail: helio.mestrALMEIDAado.unama@gmail.com

${ }^{2}$ Mestrando em Direitos Fundamentais pela Universidade da Amazônia (UNAMA), Bacharel em Direito com 10 anos de experiência jurīdica tanto na Advocacia quanto no setor público. Se interessa em pesquisar temas relativos ao Direito a cidade, nova agenda urbana e as suas relações com os direitos fundamentais à moradia, à função social da propriedade,e conexos. Universidade da Amazônia - UNAMA. bRASIL. Email: jorgeluiz_dossantos@hotmail.com

${ }^{3}$ Bacharel em Ciências Contábeis (UFPA). Bacharel em Ciências Jurídicas (UFPA). Auditor Fiscal da Secretaria Municipal de Finanças do Município de Belém/PA. Especialista em Direito Tributário (PUC/Minas Gerais). Mestre em Direito do Estado (Universidade da Amazônia - UNAMA). Ex-Professor Substituto de Direito da Universidade Federal do Pará - UFPA. Ex-Professor da Faculdade do Pará - FAP/Estácio. Professor da Faculdade Integrada BrasilAmazônia - FIBRA. Professor Titular Pós-Stricto Sensu I da Universidade da Amazônia - UNAMA. Doutor em Direito (Pontifícia Universidade Católica de São Paulo). Doutor em Desenvolvimento Sustentável do Trópico Úmido (NAEA/UFPA). Universidade da Amazônia - UNAMA. Brasil. E-mail: bruno_vieiraa@yahoo.com.br
} 
paradigma midiático que fortalece uma percepção acerca do acesso ao direito à moradia desconectada daquilo previsto na ordem jurídico-normativa nacional.

Palavras-chave: Movimentos Sociais; Ocupações; Criminalização; Imprensa Escrita; Direito à moradia.

\section{Abstract}

The article seeks to identify the dominant discursive content emitted by the brazilian printed media about the social movement for urban housing, starting from the tragedy of the case of the collapse of the Wilton Paes de Almeida building in May 2018. This is a qualitative-quantitative research that uses the technique of content analysis, through the selection of journalistic and editorial articles of the bestselling brazilian print newspapers (digital version), in the period from May 2 to 31, 2018. The most recent survey of the Circulation Verifier Institute (IVC), an organ of the National Association of Newspapers (ANJ), was adopted as the methodological criterion for selection of newspapers. The method of data analysis (keywords) collected quantitative data records through the software Search my files and later qualitative analysis of the set of records found. There was a clear tendency for the press to use words that express an ideology and a discursive content that represents prejudice, stigmatization, and imputation of criminal conduct to the social movement for urban housing. Moreover, this research is relevant for evidencing a media paradigm that strengthens a perception about access to the right to housing disconnected from what is predicted in the national legal-normative order.

Keywords: Social Movements; Occupations; Criminalization; Press Writing; Right to housing.

\section{INTRODUÇÃO}

As lutas por moradia digna que se iniciaram com o Movimento Nacional de Reforma Urbana (MNRU) na década de 1980 trouxeram muitos impactos na legislação brasileira, destacando-se a inserção na Constituição da República de 1988 em seus artigos 182 e 183 que trouxeram o tema política urbana à ordem do dia. Treze anos depois, foi a vez do Estatuto da Cidade, Lei nacional № 10.257, de 10 de julho de 2001, passar a regulamentar os dispositivos constitucionais retro mencionados.

Apesar de avanços na seara legislativa (ordem urbana), isso não foi suficiente para a efetivação do Direito Fundamental à moradia no país, insculpido no rol dos direitos sociais contidos no artigo 6o da Carta da República, através da Emenda Constitucional № 26, de 14 de fevereiro de 2000. Tal realidade é confirmada pela constatação de uma série de ocupações em imóveis urbanos que não atendem a sua função social terem se tornado, desafortunadamente, uma prática habitual no Brasil. 
A ineficiência estatal com seu aparato burocrático aliada a uma atuação selvagem do mercado imobiliário deixou uma multidão de pessoas sem acesso à habitação. São pessoas, em sua maioria, com baixa escolaridade, com poder aquisitivo reduzido e sem ter para onde ir.

Dentro deste contexto, os movimentos sociais de luta pela moradia ocuparam espaço de relevância na sociedade brasileira vez que conseguiram organizar essa massa de espoliados (KOVARICK, 1993) dando-Ihes assistência e propondo alternativas para a conquista de uma habitação digna, seja por ocupações de propriedades que não cumprem com a função social ou, ainda, por meio de demandas judiciais.

A legitimidade de tais movimentos vem se fortalecendo ante a grave crise habitacional vivenciada pelos brasileiros. Os dados oficiais revelam um déficit habitacional na faixa de 6,2 milhões de moradias no Brasil, segundo pesquisa realizada no ano de 2015 pelo Instituto Brasileiro de Geografia e Estatística (IBGE) junto a Fundação João Pinheiro, o que muito bem pode explicar no inconsciente coletivo do povo brasileiro, no que se refere a esta questão, o tão repetido mantra do "sonho da casa própria" (NALINI, 2012) refletindo e reforçando o anseio popular por um lugar decente para se morar.

Contribui para esta carência de moradas a constatação de um fenômeno lastimoso que vem se demonstrando ser um padrão nos centros urbanos das cidades brasileiras que é a existência de um grande número de imóveis ociosos, um cruel paradoxo urbano-ambiental (VIEIRA; BACELAR, 2015). Os dados referentes a esta problemática são alarmantes. Tratam-se de mais de 7 milhões de imóveis (privados e públicos) vagos nas cidades brasileiras (IBGE, 2010), constituindo-se em terrenos e construções abandonadas, casas e apartamentos ociosos ou subutilizados, principalmente, nos grandes centros urbanos.

No tocante a realidade paulistana tal problema se torna ainda mais crônico. Maior cidade da América Latina com mais de 12 milhões de habitantes, São Paulo destaca-se por seu poderio econômico sendo o principal centro financeiro, industrial e comercial do Brasil. Tais características a faz ser conhecida como a "terra das oportunidades" atraindo migrantes brasileiros, principalmente, das regiões Norte e Nordeste, além dos imigrantes de todas as partes do mundo, em especial, de países latinoamericanos como Bolívia, Peru e Haiti e, bem como, países da costa ocidental africana lusofalantes, tais quais Cabo Verde, Guiné-Bissau e Angola.

Com esse grande fluxo migratório, o aumento populacional se intensificou e como a maioria destas pessoas que chegam à São Paulo não possuem qualificação para ingresso no mercado de trabalho formal, muitos sequer possuindo qualquer entendimento sobre o idioma pátrio, por não terem onde se instalar juntam-se a imensa massa de paulistanos desempregados que residem em condições 
precárias, agravando, portanto, a crise habitacional e, em uma perspectiva mais ampla, amplificando os problemas socioespaciais.

Em 2015, segundo a Fundação João Pinheiro o déficit habitacional na região metropolitana de São Paulo era de 639 mil domicílios, ao mesmo tempo, havia 1.336.162 imóveis vagos com potencial de ocupação, em suma, uma contradição explícita que demonstra que o direito à cidade não é acessível a todos.

Sem perspectivas, sem renda fixa e lutando para sobreviver, boa parte destas pessoas transformaram-se em moradores de rua, improvisando barracos em assentamentos precários e favelas ${ }^{4}$, no qual um Estado paralelo lá existe, sendo dominado pelo tráfico de drogas, facções criminosas e pelas milícias. Ademais, podemos fazer referência aos aglomerados subnormais (IBGE, 2011), que na maioria dos casos estão localizados longe do centro dotado de infraestrutura urbana e que abriga milhões de brasileiros que vivem em situação de extrema pobreza e ausência de toda a sorte de serviços urbanos, dentre os quais, o saneamento e a moradia digna.

No entanto, milhares de brasileiros, por intermédio de movimentos sociais de luta por moradia conseguem se estabelecer em imóveis abandonados, ociosos ou subutilizados que não vem cumprindo com os ditames constitucionais de sua função social.

Este último grupo de pessoas e o seu vínculo com os movimentos organizados de luta pela moradia são os atores que interessam ao presente trabalho e que teve origem na inquietação despertada pelos pesquisadores a respeito da grande repercussão dada pela mídia escrita brasileira a respeito do desabamento do edifício Wilton Paes de Almeida, ocupado desde os anos 2000 por pessoas de baixa renda no centro da cidade de São Paulo.

O desastre, que ocorreu em 1ㅇ de maio de 2018 no largo do Paissandú, região central de São Paulo, gerou grande comoção nacional e internacional tendo colocado a questão da crise habitacional, do acesso ao Direito Fundamental à moradia no espaço urbano, as péssimas condições de vida dos habitantes de ocupações irregulares, a discussão a respeito do direito à cidade e a atuação dos movimentos sociais na pauta do debate nacional.

O objetivo do presente trabalho consiste em identificar qual o discurso dominante expressado pela mídia impressa brasileira em relação a culpabilização do movimento social de Luta pela Moradia Digna (sem-teto) na cidade de São Paulo.

\footnotetext{
4 Sobre as definições de assentamento precário e favela, sugerimos a leitura do artigo disponível em:< http://www.scielo.br/pdf/urbe/2015nahead/2175-3369-urbe-2175-3369007003A003.pdf>. Acesso em: 23 dez. 2018.
} 
Para tal mister, adotamos o método quali-quantitativo e a técnica da análise do conteúdo das reportagens e editoriais dos dois jornais impressos ou em versão digital mais vendidos do Brasil em cada uma das regiões do país. Em razão disso, adotamos como critério metodológico de seleção, o levantamento mais recente realizado pelo Instituto Verificador de Circulação (IVC), órgão vinculado a Associação Nacional de Jornais (ANJ).

Como dito acima, a pesquisa empírica utilizou-se da técnica da análise do conteúdo contido nas matérias jornalísticas no entretempo compreendido entre 2 a 31 de maio de 2018 por intermédio de coleta de dados quantitativos através do Software Search my files visando identificar a recorrência de registros das palavras-chave selecionadas nas matérias e editoriais nos jornais escolhidos nesta pesquisa. Antes, porém, será contextualizada a fatalidade que deu origem ao presente artigo.

\section{CONTEXTO SOCIAL, FÁTICO E TEMPORAL DA TRAGÉDIA OCORRIDA EM 1 DE MAIO DE 2018 NO LARGO DO} PAISSANDÚ (CENTRO DE SÃO PAULO)

Preliminarmente à abordagem da terrível tragédia que ocorreu em São Paulo na madrugada de 1 ㅇ de maio de 2018, faz-se necessária uma breve contextualização social, fático e temporal da mesma.

Construído por encomenda do empresário Sebastião Paes de Almeida na década de 1960 do século passado, o edifício Wilton Paes de Almeida teve como destinação inicial ser sede de uma empresa do setor de vidros. Situado no Largo do Paissandú, região central da maior cidade latino-americana, importante reduto boêmio e recinto de manifestações artísticas, culturais e religiosas, posteriormente, passou a ser propriedade da União tendo desempenhado um importante papel para a coletividade brasileira, uma vez que abrigou tanto a sede da Polícia Federal no Estado de São Paulo, quanto uma agência do Instituto Nacional de Seguridade Social (INSS). Leva esse nome em homenagem ao presidente do Banco Nacional do Comércio de São Paulo, instituição financeira incorporada pelo Hong Kong Shangai Bank (HSBC) desde os anos 1990.

Considerado um dos melhores exemplos da arquitetura moderna na cidade de São Paulo, a edificação fora projetada pelo arquiteto Roger Zmekhol no ano de 1961 (DOCOMO, 2018) por sua relevância arquitetônica, histórica e paisagística foi posteriormente realizado o seu tombamento no ano de 1992 pelo Conselho Municipal de Preservação do Patrimônio Histórico, Cultural e Ambiental da Cidade de São Paulo (COMPRESP). Com sua imponente fachada de vidro, o prédio foi um dos primeiros a contar com central telefônica, sistema de ar condicionado central, divisão em módulos e janelas, novidades tecnológicas da época, como se pode observar no seguinte infográfico:

\section{Figura 1: Cronologia do Edifício}




\section{Imóvel passou por diversas tentativas de revitalizaçăo}

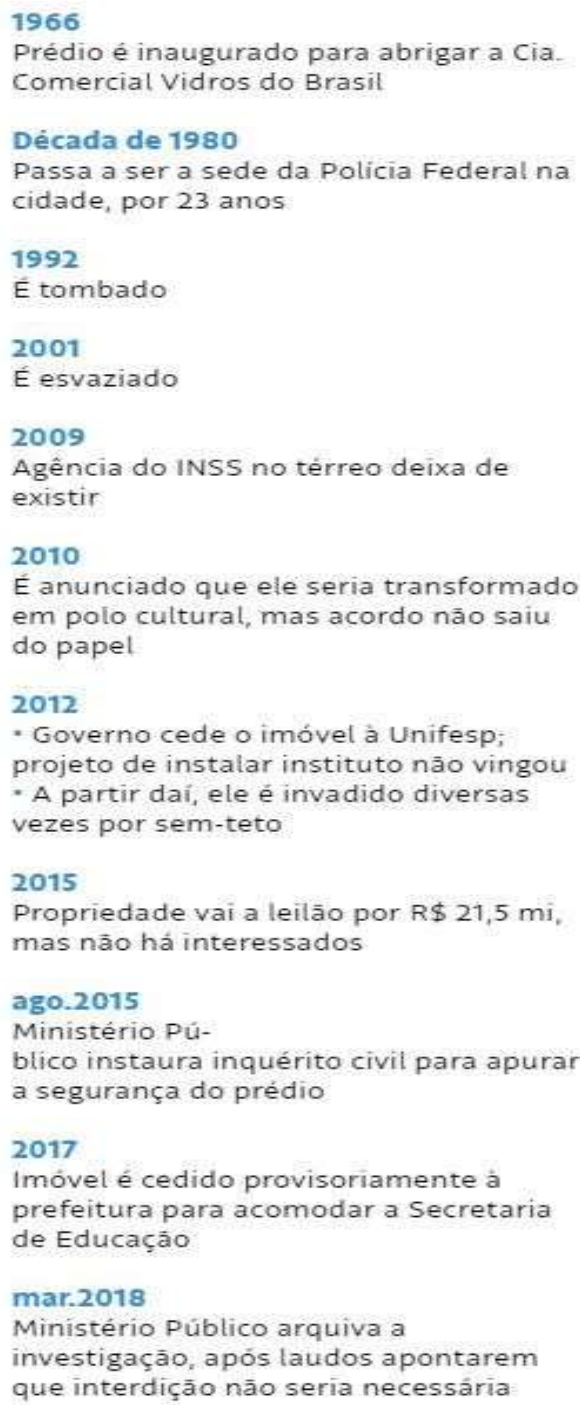

Prédio foi degradado nos últimos anos
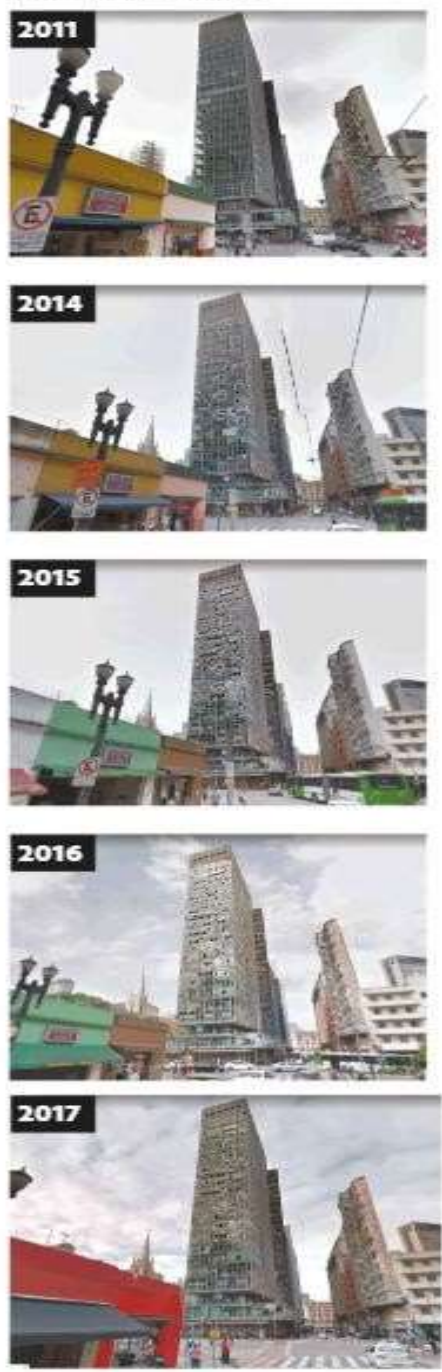

Fonte: Jornal Folha de São Paulo

Em que pese a sua relevância para a cidade, nos últimos tempos o edifício encontrava-se em crítico estado de conservação, fortemente degrado, resultado de anos de abandono materializado na visível falta de manutenção de sua estrutura elétrica, hidráulica e de sustentação. Aquela situação era fruto de uma omissão conjunta dos governos em todas as suas esferas, cenário agravado com o passar do tempo 
e cuja possível intervenção foi procrastinada de modo que a recuperação não ocorreu e um novo uso do imóvel ocorreu, isto porque dezenas de famílias de cidadãos sem-teto passaram a ocupá-lo.

Dado o fato de o edifício ter deixado de cumprir a sua função social nas últimas décadas, constatou-se que neste período uma leva de pessoas sem moradia composta por grupos familiares, mães solteiras, ex-moradores de rua, imigrantes estrangeiros, refugiados e migrantes de outros Estados da Federação se acomodaram na edificação com o apoio e organização do movimento sem teto Luta por Moradia Digna (LMD) de São Paulo.

Cumpre destacar que o apoio do referido movimento social se fazia necessário para o gerenciamento das demandas básicas de sobrevivência de seus moradores como luz, água e segurança, sendo cobrada uma taxa que variava entre $\mathrm{R} \$ 200,00$ (duzentos reais) à $\mathrm{R} \$ 400,00$ (quatrocentos reais) para cada família segundo relatos. Antes de desabar, o prédio era ocupado por 455 moradores de 171 famílias, segundo cadastro da Secretaria de Habitação do Município de São Paulo sob a coordenação do movimento LMD.

Desta forma, ante o colapso da questão habitacional já descrita, o edifício Wilton Paes de Almeida foi ocupado transformando-se em uma verdadeira "favela" vertical. As razões da ocupação são compreensíveis e legítimas do ponto de vista humanitário, revelando o fato de tantas famílias terem aceitado correr o risco de viver em um lugar sujeito a tal desfecho trágico.

A especulação imobiliária e a não aplicação dos instrumentos jurídico-urbanísticos previstos no Estatuto da Cidade são fatores que também contribuem para a espiral inflacionária dos aluguéis nos centros das cidades brasileiras e na Megalópole paulistana o quadro não poderia ser diferente. Por ser tratar do coração financeiro do país, local em que o capital dita as normas de conduta com maior vigor, pode-se afirmar que a situação é bastante grave. A título de exemplo, um cômodo de cortiço no centro não custa menos que R\$ 800,00 (oitocentos reais), enquanto um espaço delimitado por tapumes no Edifício incendiado custava até $R \$ 400$ (quatrocentos reais), segundo a matéria jornalística assinada por Bergamin Jr (2018).

Sobre a dinâmica urbana de São Paulo, a carência de política pública de moradia e as consequências advindas deste cenário, transcrevemos o seguinte fragmento:

Do ponto de vista da ação do governo (por sua intervenção direta ou pelas das políticas urbanas), as verbas públicas são, preferencialmente, alocadas nos lugares capazes de viabilizar a reprodução do capital de modo a viabilizar/fortalecer o papel econômico da metrópole de São Paulo na rede mundial das cidades. Com isso deixa de privilegiar a massa de população pobre que vai ocupar essas áreas que, em tese, não poderiam ser em hipótese alguma ocupadas, uma vez que compõem o "pulmão da cidade" ou o lugar do abastecimento de água. Essa massa de população que vive em 
condições subumanas, seja no que se refere à habitação, seja quanto à realização das necessidades básicas da vida, é duplamente penalizada no processo, num primeiro momento pela limitação de acesso à riqueza social produzida, e num segundo é tachada de inconsequente, ou sem consciência ecológica por ocupar essas áreas (CARLOS, 2009 p. 313).

Com grande parte dos seus 12.106.920 milhões de habitantes morando em regiões periféricas ou favelas sem acesso aos serviços públicos básicos como saneamento, iluminação, linhas de trem, ônibus ou metrô, o centro da capital paulista ainda se revela como melhor opção para viver ante as facilidades de menores distâncias dos postos de trabalho diminuindo desta forma os custos e o tempo gasto com transporte.

Tal realidade fica evidenciada em outros contextos de ocupações em imóveis abandonados no restante do país como o notório caso ocorrido na cidade do Rio de Janeiro em em abril de 2005 realizado pelo coletivo Ocupação Zumbi dos Palmares (OZP) em que mais de 100 pessoas ocuparam o prédio do INSS localizado na Avenida Venezuela, 53 e Ocupação Quilombo das Guerreiras (OQG) que em outubro de 2006, mais de 150 famílias ocuparam o prédio da Docas, localizado na Avenida Francisco Bicalho, 49, ambos na zona portuária, no centro do Rio de Janeiro.

Deste modo, conforme pesquisa acadêmica realizada dentro daquele contexto que no tocante à escolha de se morar no centro da cidade, observa-se que para os membros dessas ocupações:

Considerando os interesses pessoais de moradores específicos, eles revelam interesses prévios quanto à moradia no centro da cidade, tais como deixar de morar com os pais, de pagar aluguéis elevados, embora tudo isto implique morar em condições mais precárias, em termos de infra-estrutura.

(...)

Sair do aluguel caro, da casa de parentes e dos pais e buscar moradia própria no Centro, a fim de ficar mais próximo do 'trabalho', tudo isto significa exercer o direito de liberdade, o direito de buscar trabalho em condições dignas, enfim, significa participar da questão social. (FALCÃO; FALBO, 2016)

Tal realidade expõe a ferida de cerca de 250 imóveis ocupados na cidade sendo 70 deles localizados no centro.

A ocupação do prédio reflete a crise de moradia na capital mais rica do país. De acordo com a Secretaria Municipal da Habitação, há um déficit de 474 mil moradias em São Paulo e cerca de 1,2 milhão de famílias vivendo em situação precária (SÃO PAULO, 2018).

Com relação ao desabamento, teve início por volta das 1:30h da madrugada do dia 1 de maio de 2018. Tudo indica ter sido causado por um curto-circuito numa tomada com três aparelhos ligados - TV, geladeira e micro-ondas, em um cômodo onde morava uma família de quatro pessoas (SETO; GOMES, 2018). 
Por conseguinte, o fogo se propagou por todo o prédio e por volta das 2:50 h da manhã o mesmo desabou. Segundo os engenheiros, a alta temperatura deve ter atingido os pilares, estruturas que sustentam as edificações que são feitas de concreto, se deformando com o calor. O Jornal Folha de São Paulo conhecido nacionalmente pela abordagem de fatos por meio de infográficos, se utilizou bastante de tal ferramenta para detalhar o triste acontecimento aqui relatado, como se observa abaixo:

Figura 2: Infográfico da tragédia

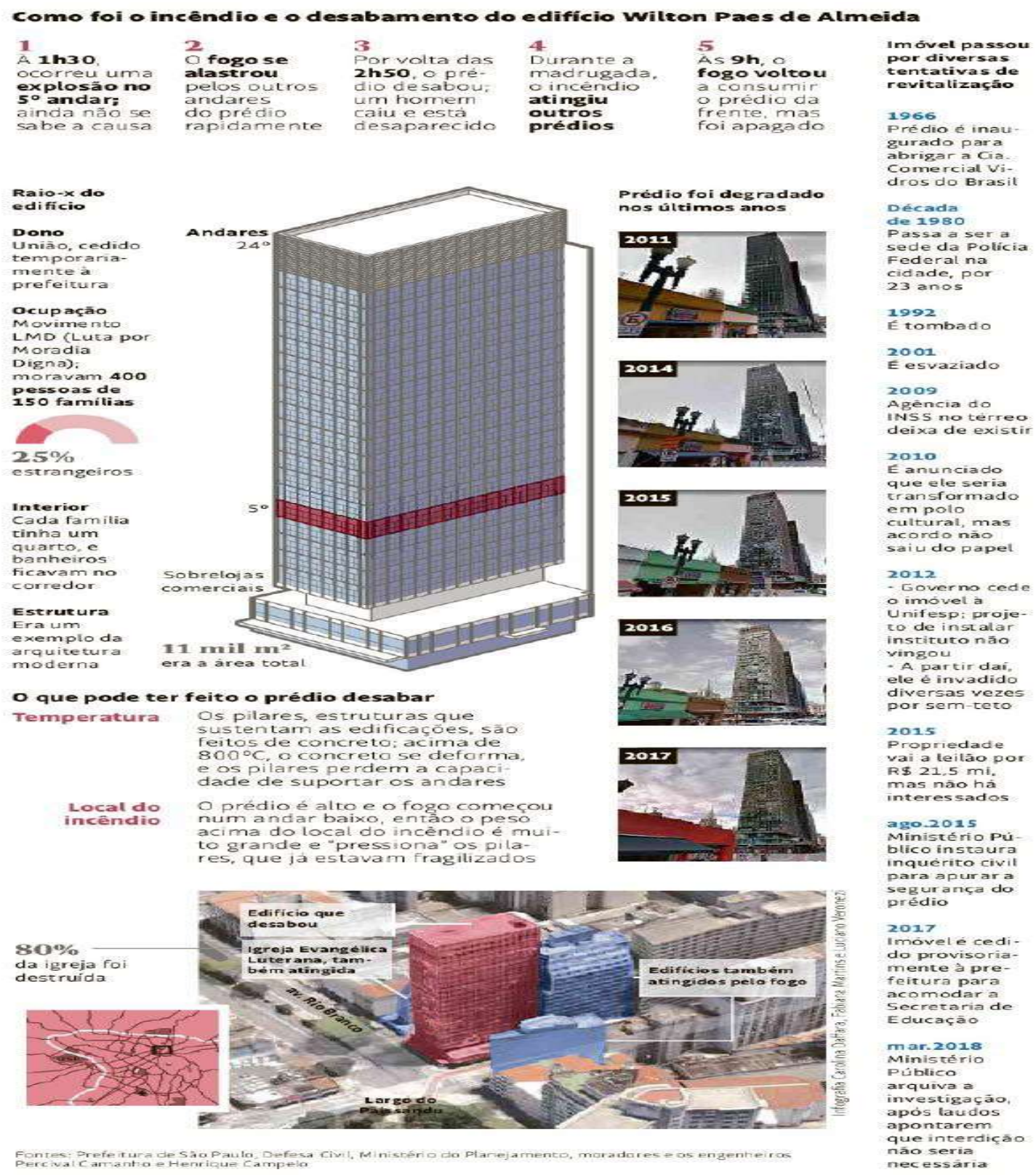

Fonte: Jornal Folha de São Paulo (2 de maio de 2018) 
Por consequência do desmoronamento, cinco edificações próximas ao edifício Wilton Paes de Almeida tiveram suas estruturas comprometidas, tendo sido as mesmas interditadas destacando-se a Igreja Evangélica Luterana de São Paulo. Cumpre destacar que no momento do desabamento houve a perda da vida de um homem conhecido como Ricardo, que ao tentar resgatar algumas vítimas quando o prédio se encontrava em chamas, desequilibrou-se caindo de elevada altura não resistindo ao impacto da queda e vindo, portanto, a óbito.

Desafortunadamente, o desastre ocorrido no Largo do Paisandú em 1ํ de maio de 2018 não foi um caso isolado. Recentemente, outros dois "incidentes", um ocorrido em São Paulo e outra na cidade de Curitiba (PR) ratificam a necessidade de pesquisas científicas relacionadas à temática da efetividade/garantia do direito à moradia, este que por sua vez, tem vínculo direto com o respeito à dignidade da pessoa humana, um dos fundamentos da República Federativa do Brasil, previsto no Art. 10 da Constituição Federal (BRASIL, 1988).

Em São Paulo, no dia 21 de novembro de 2018 um incêndio atingiu um prédio ocupado no Centro de São Paulo localizado entre a Avenida Prestes Maia e a Rua Brigadeiro Tobias 5 .O fogo atingiu o sexto andar do prédio, onde não havia ocupantes, e felizmente não houve vítimas nem desabamento da edificação vez que o fogo fora rapidamente controlado.

Na capital paranaense na noite do dia 7 de dezembro de 2018 na ocupação popular Tiradentes casas foram incendiadas supostamente por autoridades policiais ${ }^{6}$ deixando pessoas mortas dentro das casas, inclusive crianças ${ }^{7}$. Registramos, inclusive, que o título da matéria jornalística publicada no dia posterior pelo Jornal Folha de São Paulo sobre este incidente (ou seria crime?) vem carregado de um conteúdo ideológico e político, pois utiliza o termo "invasão" para qualificar um imóvel urbano ocupado por não estar cumprindo com a compulsória função social da propriedade.

\section{ATUAÇÃO DO MOVIMENTO SOCIAL POR MORADIA DIGNA}

Primeiramente, cumpre esclarecer que a caracterização dos movimentos sociais se dá por intermédio de ações sociopolíticas construídas por atores coletivos de diferentes classes sociais, em uma conjuntura específica de relações de força na sociedade civil (GOHN, 1997). Para esta categoria, já

\footnotetext{
5 Incêndio atinge prédio ocupado no Centro de São Paulo. Disponível em:https://g1.globo.com/sp/saopaulo/noticia/2018/11/21/incendio-atinge-predio-ocupado-no-centro-de-sao-paulo.ghtml. Acesso em: $23 \mathrm{dez}$. 2018.

6 Incêndio destrói 300 casas em área de invasão na periferia de Curitiba. Disponível em:https://www1.folha.uol.com.br/cotidiano/2018/12/incendio-destroi-300-casas-em-area-de-invasao-naperiferia-de-curitiba.shtml. Acesso em: 23 dez. 2018.

${ }^{7}$ Vídeo mostra homens com coletes da PM atirando em área incendiada em Curitiba. Disponível em:https://www1.folha.uol.com.br/cotidiano/2018/12/video-mostra-homens-com-coletes-da-pm-atirando-emarea-incendiada-em-curitiba.shtml. Acesso em: 23 dez. 2018.
} 
consolidada academicamente, as ações desenvolvem um processo de criação de identidades em espaços coletivos não institucionalizados, gerando transformações na sociedade, seja de caráter conservador ou progressista (GOSS; PRUDENCIO, 2004).

Por influência das ideias seminais de Lefebvre (2001), pai da teoria do "Direito à Cidade", os movimentos sociais urbanos aderiram à sua pauta de reivindicações, incluindo o exercício de direitos à moradia, o respeito à população de rua, o direito ao transporte público de qualidade e à mobilidade, à defesa de espaços públicos de convivência e o direito à liberdade de manifestação (este tão ameaçado na atual conjuntura política), consolidando-se como síntese de reivindicações por novas formas de construção e de vivência do espaço urbano.

A cidade é um objeto de direito para os sujeitos que nela vivem e circulam. Critica-se, desse modo, a forma como as cidades são produzidas e apropriadas pela lógica da acumulação e reprodução do capital (HARVEY, 2012), destacando o papel indispensável dos movimentos sociais urbanos que congregam e articulam diferentes atores na luta em face da hegemonia do capital, movimentos estes fundamentais na perspectiva de uma revolução urbana transformadora.

Fruto de efervescência popular e do desgaste do regime militar que já se encontrava em processo de transição lenta, gradual e segura para a democracia nos últimos dois mandatos do regime militar no Brasil, surge na década de 1980 no Brasil o Movimento Nacional pela Reforma Urbana (MNRU), formado por organizações não-governamentais, associações de moradores, movimentos sociais por moradia e associações profissionais (SAULE JR.; UZZO, 2010).

A agenda de reivindicações políticas desse período organizava-se sob a ideia de reforma urbana (BONDUKI, 2009) e tinha como centralidade o direito à moradia, que se relacionava com outros temas como transporte público e acesso ao trabalho.

O MNRU foi um ator protagonista da inclusão do capítulo sobre a Política Urbana na Constituição de 1988, que definiu a competência dos municípios para aprovar o plano diretor de desenvolvimento urbano e nele estabelecer os meios para realizar as funções sociais da cidade. Suas lutas também contribuíram para a elaboração e aprovação da Lei Federal no 10.257/2001, denominada Estatuto da Cidade.

Dentro deste contexto eclodiram uma série de lutas por moradia no Brasil capitaneados por diversos grupos organizados, sendo os mais representativos a Frente de Luta por Moradia, Movimento dos Trabalhadores Sem-Teto e União dos Movimentos de Moradia. No caso discutido no presente trabalho o grupo a frente da ocupação do Edifício Wilton Paes de Almeida era o grupo Luta por Moradia Digna (LMD). 
A Frente de Luta por Moradia (FLM) foi criada em 2004 a partir da junção de outras legendas, como o Movimento Sem-Teto do Centro (MSTC), foi inspirado na experiência de mutirões de autogestão e hoje tem como foco o centro de São Paulo.

O Movimento dos Trabalhadores Sem-Teto (MTST) foi criado em 1997 como experiência do Movimento dos Trabalhadores Rurais Sem Terra (MST) para ocupação de "latifúndios improdutivos" nas periferias de grandes cidades. Sua principal liderança é, atualmente, Guilherme Boulos; candidato derrotado à presidência do Brasil em 2018.

A União dos Movimentos de Moradia (UMN foi criada em 1987 para articular movimentos de moradia na Grande São Paulo, engloba outras siglas históricas, como o Movimento de Moradia do Centro (MMC) e a Unificação da Luta de Cortiços (ULC)

O Movimento de Luta por Moradia Digna (LMD) faz parte do mesmo grupo do Movimento de Luta Social por Moradia (MLSM), ascendeu em 2014 ao ocupar edifícios públicos no centro de São Paulo.

A ocupação de prédios que não cumprem sua função social teve início nos anos 1990. Além de organizar famílias que buscavam um abrigo próximo ao trabalho, os movimentos de moradia denunciam a especulação imobiliária e pressionam o poder público por programas de produção de habitação no centro.

Deste modo, pode-se afirmar que a relação entre a eficácia do direito à cidade na realidade urbana brasileira perpassa necessariamente pela atuação dos movimentos sociais urbanos de cunho emancipatório que lograram inscrever suas demandas nas agendas políticas contemporâneas.

Assim, partindo-se da premissa de que o direito à cidade ultrapassa a questão da gestão pública, o exercício político revolucionário, como participação direta, permanente e integrativa é fundamental para que os indivíduos alcancem os seus direitos constitucionalmente assegurados exercendo assim plenamente a cidadania (SANTOS, 2014).

Os movimentos sociais tem como característica a definição de bandeiras e princípios criando mobilizações por determinadas pautas coletivas, contando com a possibilidade de interlocução com agentes do governo para apresentar suas reivindicações possuindo grande parcela de contribuição para a efetivação do direito fundamental à moradia, características estas desconsideradas no tratamento dado a estes por ocasião da cobertura jornalística por ocasião do desabamento do edifício em São Paulo como se constata no capítulo seguinte.

DA COBERTURA DA MÍDIA IMPRESSA SOBRE O CASO DO DESABAMENTO DO EDIFÍCIO WILTON PAES DE ALMEIDA 
Antes de adentrarmos a análise de conteúdo contido nas matérias jornalísticas cumpre esclarecer qual foi o critério metodológico utilizado no presente trabalho. O corte espacial é todo o território brasileiro, assim como, o recorte temporal considera o entretempo dos dias 02 a 31 de maio. Assim, foram selecionadas todas as matérias jornalísticas e editoriais dos jornais selecionados que, respeitando tais critérios, abordaram tanto a tragédia do Largo do Paissandú quanto a discussão suscitada pela violação do direito fundamental à moradia no país.

Desse modo, visando verificar as tendências editoriais e o conteúdo discursivo, foram selecionadas reportagens e editoriais acerca do desabamento do Edifício Wilton Paes de Almeida. Destarte, o corpus da pesquisa está materializado por dois jornais com maior circulação em cada uma das regiões administrativas do país; no total dez jornais brasileiros constituem a fonte de informações desta pesquisa. A escolha dos veículos de imprensa está embasada no levantamento mais recente realizado pelo Instituto Verificador de Circulação (IVC), órgão vinculado a Associação Nacional de Jornais (ANJ), realizado no ano de 2015.

Assim, os jornais impressos de maior circulação e com matérias analisadas para a realização do presente trabalho estão consolidados no quadro seguinte.

Quadro 01: Jornais pesquisados por região administrativa

\begin{tabular}{|l|l|l|}
\hline Região Administrativa & \multicolumn{1}{|c|}{ Jornal 1 } & \multicolumn{1}{|c|}{ Jornal 2 } \\
\hline Sudeste & Folha de São Paulo (SP) & Globo (RJ) \\
\hline Sul & Zero Hora (RS) & Correio do Povo (RS) ${ }^{1}$ \\
\hline Centro Oeste & Daqui (GO) & Correio Braziliense (DF) \\
\hline Nordeste & Correio (BA) & Jornal do Commércio (PE) \\
\hline Norte & 10 Minutos (AM) & Diário do Pará (PA) \\
\hline
\end{tabular}

Visando promover a análise do conteúdo discursivo contido nas reportagens e editoriais e suas respectivas linhas ideológicas, decidimos utilizar o aplicativo Search my File, a partir da definição de um conjunto de palavras-chave. Destarte, ao adotar tais modalidades de parâmetros para a análise dos dez 
veículos de imprensa selecionados, levamos em consideração as dimensões continentais e as diferenças étnico-culturais de cada uma das cinco regiões político-administrativas do país, possibilitando assim uma visão panorâmica do objeto da pesquisa e um refino nas conclusões qualitativas, aproximando-se desta maneira, o máximo possível, do retrato da realidade.

Com relação às palavras-chave escolhidas objetivando realizar a análise do conteúdo, relacionamos todas (com suas variações), conforme abaixo enumeradas: 1 ) invasão e seus derivados (invasores, invadido); 2) Milícia; 3) Faç̧ão/ões; 4) Aproveitador/es; 5) Crime/Criminosos/as; 6) Oportunista/as; 7) Cobrança; 8) Malandro/os; 9) Aluguel/éis; 9) Bandido/os/agens; e 10) llegal.

\section{REGIÃO SUDESTE}

Se dará início pela análise dos veículos da região Sudeste, por uma razão óbvia: foi lá onde ocorreu o fato. Por tal motivo, foi dada atenção especial às reportagens e editoriais publicados no Jornal Folha de São Paulo, pois além de ser o veículo de maior circulação na Região, foi o que realizou a cobertura mais detalhada dentre todos os demais jornais das outras regiões do país. Ademais, há o nítido interesse local pelo tema que afeta diretamente os moradores da cidade de São Paulo, conforme pode ser observado no gráfico 1 logo em seguida.

\section{Gráfico 1: Gráfico 1: Quantidade de matérias por jornal}

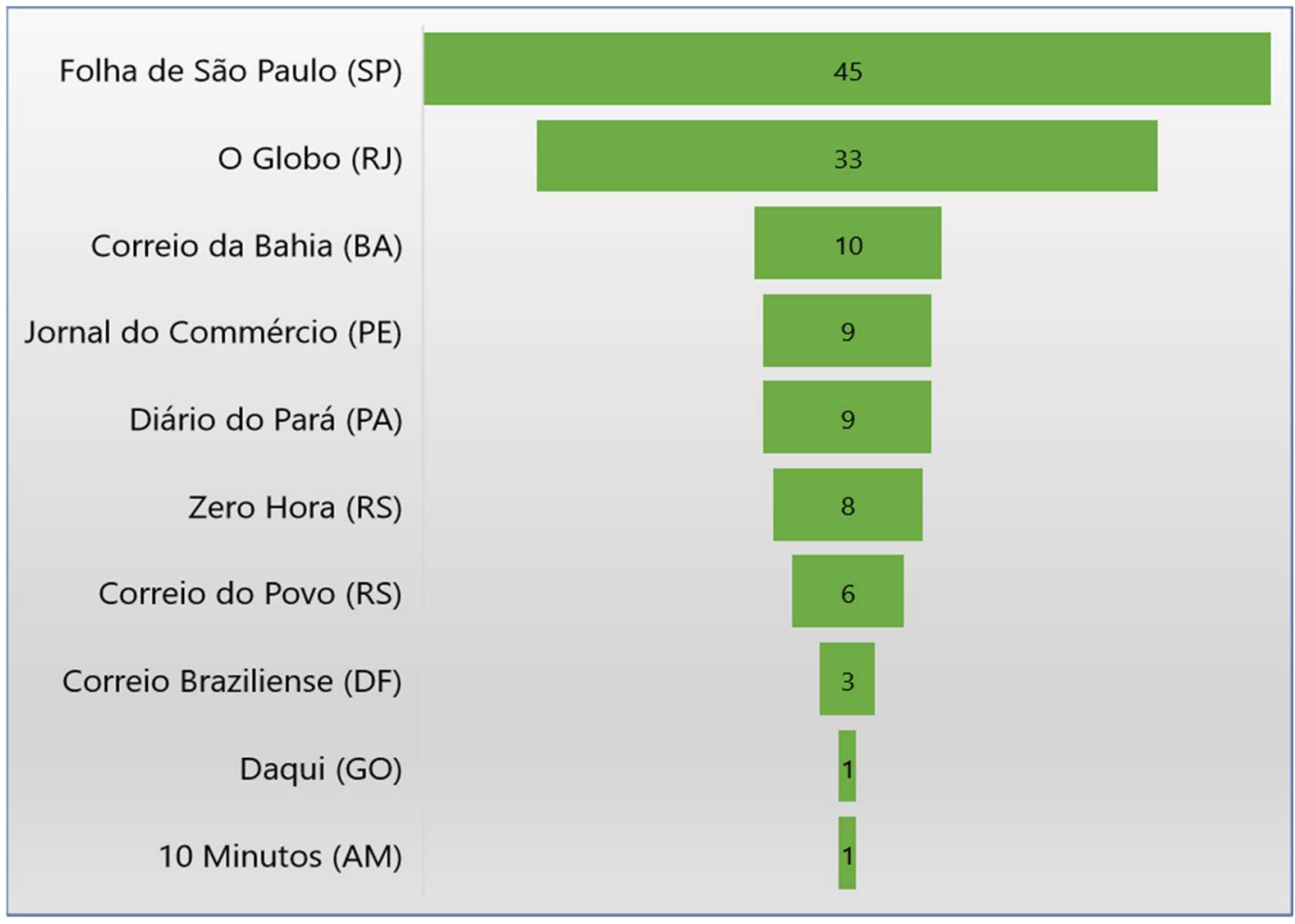


Fonte: Elaboração dos autores

Como não poderia deixar de ser, devido a excepcionalidade e as proporções do fato, o desabamento ${ }^{8}$ do edifício no centro de São Paulo ganhou grande destaque já na capa principal da edição de 02/05/2018:

Figura 3: Capa do Jornal Folha de São Paulo

\section{FOLHA DE S.PAULO}

DESDE 1921 * $\star$ UM IOHNAL A SERVICO DO BRASIL

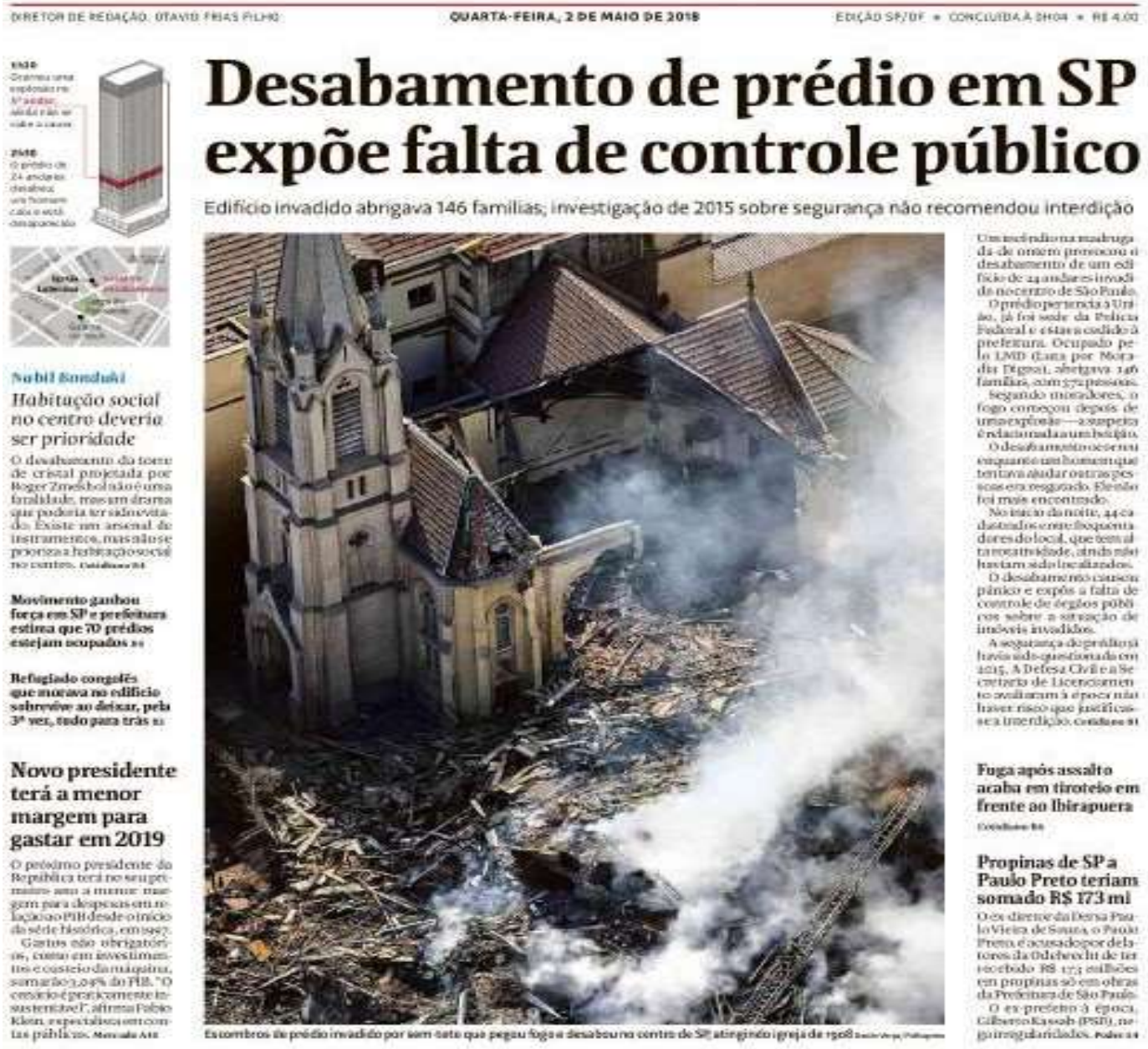

Fonte: Jornal Folha de São Paulo (2 de maio de 2018)

Já na primeira matéria que aborda com profundidade a tragédia, o Jornal Folha de São Paulo de 02/05/2018, na coluna Cotidiano, tem o seguinte título: "PRÉDIO INVADIDO DESABA E EXPÕE RISCOS

\footnotetext{
${ }^{8}$ Apesar de não ser este o objeto desta pesquisa, é possível argumentar que a tragédia do Largo do Paissandú pode ser alvo de reparação civil por parte do Estado, devido a sua omissão em garantir moradia digna às famílias.
} 
EM SP". Sem nenhum pudor de ocultar a linha editorial do jornal, logo de plano, a Folha de São Paulo trata como invasores os moradores do edifício, como pode ser observado na imagem abaixo.

Figura 4: Coluna Cotidiano

B 4 QUARTA-FEIRA, 2 DE MAIO DE 2018

cotidiano

\section{Centro de São Paulo tem 70 prédios invadidos}

Grupos sem-teto avançaram com alta de aluguéis e política habitacional inadequada para a regiăo central, dizem urbanistas

Fonte: Jornal Folha de São Paulo

O Jornal Folha de São Paulo omite, no entanto, dados fundamentais que levaram a ocupação do prédio já descritos no presente artigo. O termo "invadido" revela preconceito e pela linguagem empregada, revela agressividade em relação às pessoas que não dispõem de moradia que lhes permita garantir a dignidade necessária a todo ser humano.

De acordo com o dicionário digital da língua portuguesa, "invasão" significa: 1. Ato ou efeito de invadir; e 2. Entrada violenta ou arrogante (PRIBERAM, 2018). Logo, invadir entende-se penetrar num determinado lugar e ocupá-lo pela força. Desta forma, como podem os moradores do Paes de Almeida o terem invadido se não houve qualquer registro de violência? Tiraram a força de quem? O imóvel estava abandonado, sem cumprir, portanto, com a sua função social. Destarte, entendemos que o termo mais isento a ser utilizado na matéria jornalística seria "ocupar", o que, numa apertada síntese, significa: 1) tomar ou estar na posse de; 2) exercer o controle sobre determinado espaço; 3) preencher um espaço ou um território; 4) estar instalado em determinado lugar; 5) habitar; e 6) morar (PRIBERAM, 2018).

Para a imprensa paulistana o pré-julgamento das pessoas que habitavam naquelas condições insalubres, bem como, o Movimento Luta por Moradia Digna (MLD) foi imediato imputando uma conduta criminosa aos mesmos. Para o Jornal, não é levado em consideração o fato de a ocupação do imóvel ter sido a única alternativa que restou para morar no centro e, portanto, próximo aos locais de trabalho e aos serviços públicos (comodidade e qualidade mínima de vida). Dito de outro modo, a conteúdo jornalístico desconsiderou totalmente as razões de ordem subjetiva e econômica que levaram 
brasileiros e brasileiros a ocuparam o prédio em questão, retratando, em breve metáfora, apenas a ponta de um iceberg e desprezando a maior parte do grande bloco de gelo.

Segue abaixo a síntese dos dados extraídos, a partir das palavras-chave selecionadas, e alimentadas no software Search my file, com base nas reportagens, notícias e editoriais publicados nos jornais da Região Sudeste e, posteriormente, nos demais subcapítulos os dados relativos às demais regiões administrativas do país.

\section{Quadro 02: $\quad$ Folha de São Paulo (SP)}

\begin{tabular}{|l|l|l|l|l|}
\hline Palavras-chave & $02 / 05$ a 05/05 & $06 / 05$ a 12/05 & $13 / 05$ a 19/05 & 20/05 a 31/05 \\
\hline Invasão/ões, invasores, invadido/os/a/as & 17 & 13 & 4 & - \\
\hline Milícia & - & 1 & - & - \\
\hline Facção/ões & 4 & - & - & - \\
\hline Aproveitador/es & - & - & - & - \\
\hline Crime, criminoso/os/a/as & 5 & 1 & - & - \\
\hline Oportunista/as & - & - & - & - \\
\hline Cobrança & 4 & 1 & 1 & - \\
\hline Malandro/os & - & - & - & - \\
\hline Aluguel/éis & 10 & 7 & 4 & - \\
\hline Bandido/os/a/as/agem & 1 & 1 & - & - \\
\hline Ilegal & 2 & - & - & - \\
\hline Totais & 45 & 24 & 9 & - \\
\hline
\end{tabular}

Fonte: Elaboração dos autores

Dentre todos os jornais analisados, a Folha de São Paulo é a fonte de coleta de informações que revela o maior número de registros das palavras-chave pesquisadas. Como hipótese, deve-se a isso o fato de ser o aludido periódico estar sediado no local do desastre/tragédia. Ademais, é um meio de comunicação impresso extenso, com muitos colunistas, espaço para opinião de autoridades políticas e acadêmicas, além de possuir tradição em aprofundar temas de repercussão nacional ou internacional, haja vista a sua preocupação em confecção de gráficos, tabelas e infográficos sendo por tradição um dos jornais brasileiros que são exemplos de jornais de referência ao lado do O Estado de São Paulo e o Jornal

do

Brasil

(SOUSA,

2005).

Ganham destaques as palavras-chave, "invasão" e seus derivados com 34 registros, "aluguéis" com 21 aparições, "facção" com 4 ocorrências e a palavra-chave "milícia" com 1 registro. A análise do 
conteúdo discursivo começa a revelar uma linha editorial que, apesar de não ter mencionado as palavras-chaves "oportunista", "aproveitador" e "malandro", evidencia pouca margem de isenção, denotando uma tendência a criminalizar os movimentos sociais, pois os termos (palavras-chave) encontrados no corpus da pesquisa carregam carga valorativa bem acentuada.

Na sequência, o quadro abaixo demonstra o quantitativo de ocorrências das palavras-chave observadas nas matérias e editoriais do jornal o Globo, sediado no Estado do Rio de Janeiro e que, por compor as organizações Globo, o conteúdo discursivo emitido acompanha a linha editorial dos demais veículos de informação do grupo e exercem relevante influência política, social e econômica na sociedade brasileira, conforme Brittos (2005, p. 126) informa: "apesar da crise financeira que ronda algumas áreas de atuação das OG - em especial a TV a cabo -, não há sinais de que o protagonismo exercido na política brasileira ao longo das últimas décadas tenha diminuído".

Fundado em 1925, possui circulação nacional por meio de assinatura mensal nas formas impressa ou digital. De orientação política conservadora, é um dos jornais de maior tiragem do país, considerado pelo portal jornalístico media and comunication $\mathrm{Brazil}^{9}$ um dos mais relevantes periódicos brasileiros.

Quadro 03: O Globo (RJ)

\begin{tabular}{|l|l|l|l|l|}
\hline Palavras-chave & $\mathbf{0 2 / 0 5}$ a 05/05 & $\mathbf{0 6 / 0 5}$ a 12/05 & $\mathbf{1 3 / 0 5}$ a 19/05 & 20/05 a 31/05 \\
\hline Invasão/ões, invasores, invadido/os/a/as & 14 & - & 4 & - \\
\hline Milícia & 5 & - & 2 & - \\
\hline Facção/ões & 3 & - & 1 & - \\
\hline Aproveitador/es & - & - & - & - \\
\hline Crime, criminoso/os/a/as & 7 & - & 2 & - \\
\hline Oportunista/as & - & - & - & - \\
\hline Cobrança & 2 & 1 & - & - \\
\hline Malandro/os & - & - & - & - \\
\hline Aluguel/éis & - & 1 & 3 & - \\
\hline Bandido/os/a/as & 13 & 1 & 3 & - \\
\hline Ilegal & 1 & - & 1 & - \\
\hline Totais & - & 3 & 16 & - \\
\hline
\end{tabular}

9 Media and Communications: Brazil. Disponível em: http://web.archive.org/web/20060225115053/http://www.loc.gov/rr/international/hispanic/brazil/resources/m edia.html. Acesso em: 21 nov. 2018. 
Fonte: Elaboração dos autores

Como resultado da análise do conteúdo discursivo expresso nas reportagens e editoriais, constatamos 18 registros da palavra-chave "invasão" e seus derivados, 7 da palavra-chave "milícias", 4 registros da palavra-chave "facções", 16 ocorrências da palavra-chave "aluguel" e 5 registros relacionados à palavra-chave "bandidos". Do levantamento dos dados quantitativos, percebemos a inclinação de um conteúdo discursivo pró-criminalização dos movimentos sociais, pois as palavraschave recorrentemente emitidas pelo jornal pesquisado, pela força do significado de cada uma, têm um poder de impor um determinado entendimento sobre a problemática da luta por moradia digna no Brasil.

REGIÃO SUL

Quadro 04: Correio do Povo (RS)

\begin{tabular}{|c|c|c|c|c|}
\hline Palavras-chave & $02 / 05$ a $05 / 05$ & $06 / 05$ a $12 / 05$ & $13 / 05$ a $19 / 05$ & $20 / 05$ a $31 / 05$ \\
\hline Invasão/ões, invasores, invadido/os/a/as & - & 2 & - & - \\
\hline Milícia & - & 1 & - & - \\
\hline Facção/ões & - & - & - & - \\
\hline Aproveitador/es & - & - & - & - \\
\hline Crime, criminoso/os/a/as & - & - & - & - \\
\hline Oportunista/as & - & - & - & - \\
\hline Cobrança & - & - & - & - \\
\hline Malandro/os & - & - & - & - \\
\hline Aluguel/éis & 2 & 1 & - & - \\
\hline Bandido/os/a/as/agem & - & - & - & - \\
\hline Ilegal & - & - & - & - \\
\hline Totais & 2 & 4 & - & - \\
\hline
\end{tabular}

Fonte: Elaboração dos autores

Quadro 05: Zero Hora (RS)

\begin{tabular}{|l|l|l|l|l|}
\hline Palavras-chave & $02 / 05$ a 05/05 & $06 / 05$ a 12/05 & $13 / 05$ a 19/05 & 20/05 a 31/05 \\
\hline Invasão/ões, invasores, invadido/os/a/as & 3 & - & 1 & - \\
\hline Milícia & - & - & - & - \\
\hline
\end{tabular}




\begin{tabular}{|l|l|l|l|l|}
\hline Facção/ões & - & - & - & - \\
\hline Aproveitador/es & - & - & - & - \\
\hline Crime, criminoso/os/a/as & 1 & - & - & - \\
\hline Oportunista/as & - & - & - & - \\
\hline Cobrança & - & - & - & - \\
\hline Malandro/os & - & - & - & - \\
\hline Aluguel/éis & 2 & - & 1 & - \\
\hline Bandido/os/a/as/agem & - & - & - & - \\
\hline Ilegal & - & - & - & - \\
\hline Totais & 6 & - & 2 & - \\
\hline
\end{tabular}

Fonte: Elaboração dos autores

Os jornais gaúchos, representantes da Região Sul do Brasil revelaram-se discretos ao tratarem do tema alusivo ao desabamento do Edifício Wilton Paes de Almeida. Observamos que durante todo o mês de maio de 2018 houve interesse da mídia Rio Grandense em noticiar o fato. Todavia, esta repercussão foi bem aquém daqueles observado nos jornais de circulação na região sudeste.

Entretanto, as matérias e editoriais que abordaram o tema trouxeram opiniões de especialistas, bem como, objetivaram promover o debate sobre a realidade local matérias envolvendo a temática do déficit habitacional.

Em que pese a comedida cobertura, levando-se em consideração a proximidade geográfica da Região Sul com a cidade de São Paulo, mesmo assim, constatamos a presença de registros de palavraschave de natureza incriminatória/condenatória, de acordo com os registros nas reportagens, destacando-se: "Invasão/ões" e seus correlatos com 7 ocorrências, bem como, a palavra-chave "milícia" com um único registro. Entretanto, não foram registradas ocorrências das demais palavras-chave selecionadas na pesquisa, possibilitando compreender que o conteúdo discursivo expresso nos jornais gaúchos apresenta uma narrativa criminalizadora inferior se compararmos com os jornais sediados na região sudeste.

REGIÃO CENTRO-OESTE

Quadro 06: Correio Braziliense (DF) 


\begin{tabular}{|l|l|l|l|l|}
\hline Invasão/ões, invasores, invadido/os/a/as & 2 & - & - & - \\
\hline Milícia & - & - & - & - \\
\hline Facção/ões & - & - & - & - \\
\hline Aproveitador/es & - & - & - & - \\
\hline Crime, criminoso/os/a/as & - & - & - & - \\
\hline Oportunista/as & - & - & - & - \\
\hline Cobrança & - & - & 1 & - \\
\hline Malandro/os & - & - & - & - \\
\hline Aluguel/éis & 1 & - & 1 & - \\
\hline Bandido/os/a/as/agem & - & - & - & - \\
\hline Ilegal & - & - & - & - \\
\hline Totais & 3 & - & 2 & - \\
\hline
\end{tabular}

Fonte: Elaboração dos autores

Quadro 07: Daqui (GO)

\begin{tabular}{|l|l|l|l|l|}
\hline Palavras-chave & $\mathbf{0 2 / 0 5}$ a 05/05 & $\mathbf{0 6 / 0 5}$ a 12/05 & $\mathbf{1 3 / 0 5}$ a 19/05 & 20/05 a 31/05 \\
\hline Invasão/ões, invasores, invadido/os/a/as & - & - & - & - \\
\hline Milícia & - & - & - & - \\
\hline Facção/ões & - & - & - & - \\
\hline Aproveitador/es & - & - & - & - \\
\hline Crime, criminoso/os/a/as & - & - & - & - \\
\hline Oportunista/as & - & - & - & - \\
\hline Cobrança & - & - & - & - \\
\hline Malandro/os & - & - & - & - \\
\hline Aluguel/éis & - & - & - & - \\
\hline Bandido/os/a/as/agem & - & - & - & - \\
\hline Ilegal & - & - & - & - \\
\hline Totais & - & - & - & - \\
\hline
\end{tabular}

Fonte: Elaboração dos autores

A região Centro-Oeste do Brasil, tem como um dos periódicos de destaque o Correio Braziliense (DF), sediado na capital da República. Tal jornal interessou-se pela cobertura do caso do desabamento, 
tendo sido detectado no periódico, por intermédio do software utilizado nesta pesquisa, o registro de um total de 5 repetições de palavras-chave de cunho incriminador, destacando-se: "Invasão/ões) e seus congêneres com 2 ocorrências e a palavra-chave "cobrança" com 1 único registro.

Observa-se que o Jornal DAQUI (GO) em formato tablóide, limitou-se a tão somente relatar a tragédia no dia posterior à tragédia (02 de maio de 2018) não tendo emitido nenhum conteúdo opinativo ou referência ao longo do mês de maio de 2018. Diante disso, não registramos a presença de nenhuma palavra-chave através da compilação realizada pelo Software Search my files.

Logo, em uma comparação com as regiões sudeste, locus do epicentro da tragédia em questão e demais regiões do país, constatamos que no centro-oeste brasileiro foi a região na qual houve menor interesse pela temática da moradia nos centros urbanos, conforme pode ser observado no gráfico 1 na sequência representado. No entanto, apesar do baixíssimo interesse pela temática pesquisada, ainda foram registradas nas reportagens publicadas pelo Jornal Correio Braziliense expressões de cunho depreciativo e que imprimem uma narrativa condenatória à ação dos movimentos sociais que atuam em favor do direito à moradia, tal como, o recorrente termo "invasão" e suas derivações.

\section{REGIÃO NORDESTE}

Quadro 08: Correio da Bahia (BA)

\begin{tabular}{|l|l|l|l|l|}
\hline Palavras-chave & $\mathbf{0 2 / 0 5}$ a 05/05 & $\mathbf{0 6 / 0 5}$ a 12/05 & 13/05 a 19/05 & 20/05 a 31/05 \\
\hline Invasão/ões, invasores, invadido/os/a/as & 1 & 1 & - & - \\
\hline Milícia & 1 & 1 & - & - \\
\hline Facção/ões & - & - & - & - \\
\hline Aproveitador/es & - & - & - & - \\
\hline Crime, criminoso/os/a/as & - & - & - & - \\
\hline Oportunista/as & - & - & - & - \\
\hline Cobrança & 3 & - & - & - \\
\hline Malandro/os & - & - & - & - \\
\hline Aluguel/éis & - & 2 & - & - \\
\hline Bandido/os/a/as/agem & 3 & 1 & - & - \\
\hline Ilegal & - & - & - & - \\
\hline Totais & - & 5 & - & - \\
\hline
\end{tabular}

Fonte: Elaboração dos autores 
Quadro 09: Jornal do Commércio (PE)

\begin{tabular}{|c|c|c|c|c|}
\hline Palavras-chave & $02 / 05$ a $05 / 05$ & $06 / 05$ a $12 / 05$ & $13 / 05$ a $19 / 05$ & $20 / 05$ a $31 / 05$ \\
\hline Invasão/ões, invasores, invadido/os/a/as & 2 & - & - & - \\
\hline Milícia & - & - & - & - \\
\hline Facção/ões & - & - & - & - \\
\hline Aproveitador/es & - & - & - & - \\
\hline Crime, criminoso/os/a/as & - & - & - & - \\
\hline Oportunista/as & - & - & - & - \\
\hline Cobrança & - & 1 & - & - \\
\hline Malandro/os & - & - & - & - \\
\hline Aluguel/éis & 4 & 1 & - & 1 \\
\hline Bandido/os/a/as/agem & - & - & - & - \\
\hline Ilegal & - & - & - & - \\
\hline Totais & 6 & 2 & - & 1 \\
\hline
\end{tabular}

Fonte: Elaboração dos autores

Os jornais situados na região nordeste escolhidos para esta pesquisa deram significativa importância ao tema abordado, realizando uma cobertura com grau de complexidade e demonstrado interesse ao longo do marco temporal adotado na presente pesquisa. Nos jornais nordestinos, a importância à questão da moradia urbana e demais temas relacionados ganhou maior espaço na mídia impressa nacional se confrontarmos com as demais regiões, exceto, com relação aos jornais da região sudeste brasileiro, como pode ser observado no gráfico seguinte:

Gráfico 2: Repercussão da mídia sobre a tragédia por região administrativa (\%)

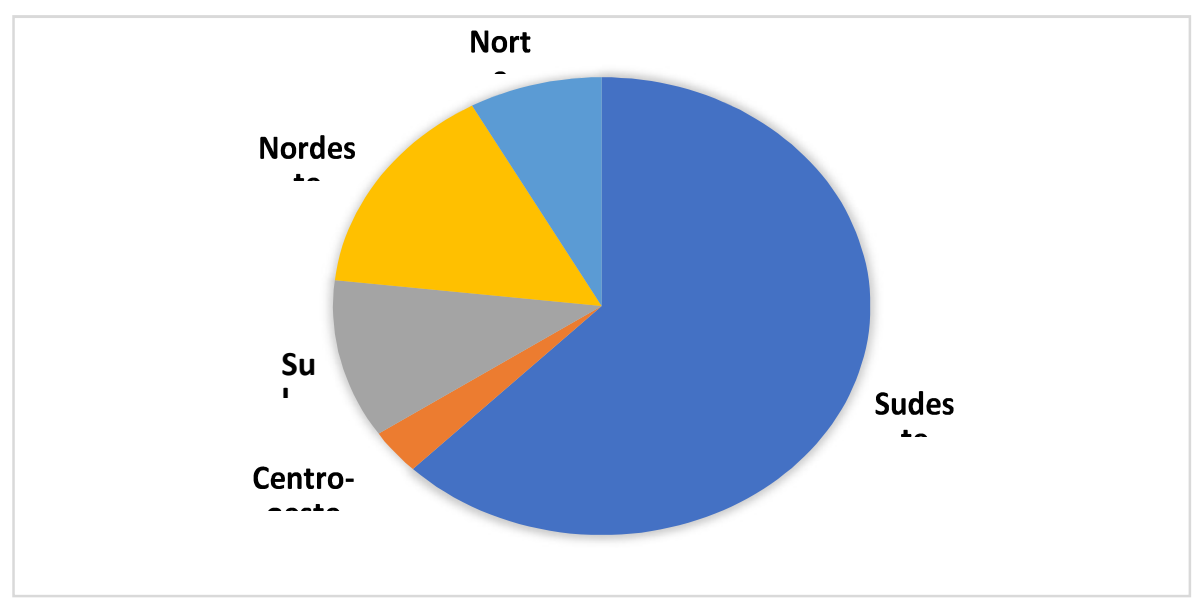




\section{Fonte: Elaboração dos autores}

Registramos que nos jornais selecionados para representar a região nordeste não foram registradas as palavras-chave: "facção/ções", "aproveitador/es", "crime/criminosos", "oportunistas", "malandro/os" e "ilegal", palavras que carregam forte carga valorativa depreciativa e criminalizadora quando inserido no contexto do debate sobre o direito à moradia. Contudo, ainda sim, constatamos 22 registros de palavras-chave que estão inseridas em uma narrativa criminalizadora dos movimentos sociais que defendem o direito à moradia digna, tais como: "invasão/ões", "invasores", "invadido/os/a/as" com 4 ocorrências, "cobrança" em quatro momentos, "milícia" com 2 registros e a palavra-chave "aluguéis", dentro de um contexto de ilegalidade com 11 repetições.

\section{REGIÃO NORTE}

Quadro 10: Diário do Pará (PA)

\begin{tabular}{|l|l|l|l|l|}
\hline Palavras-chave & $\mathbf{0 2 / 0 5}$ a 05/05 & $\mathbf{0 6 / 0 5}$ a 12/05 & $13 / 05$ a 19/05 & 20/05 a 31/05 \\
\hline Invasão/ões, invasores, invadido/os/a/as & - & - & - & - \\
\hline Milícia & - & - & - & - \\
\hline Facção/ões & - & - & - & - \\
\hline Aproveitador/es & - & - & - & - \\
\hline Crime, criminoso/os/a/as & - & - & - & - \\
\hline Oportunista/as & - & - & - & - \\
\hline Cobrança & - & - & - & - \\
\hline Malandro/os & - & - & - & - \\
\hline Aluguel/éis & 1 & 1 & - & 1 \\
\hline Bandido/os/a/as/agem & - & - & - & - \\
\hline Ilegal & - & - & - & - \\
\hline Totais & 1 & 1 & - & 1 \\
\hline
\end{tabular}

Fonte: Elaboração dos autores 
Quadro 11: 10 Minutos (AM)

\begin{tabular}{|c|l|l|l|l|}
\hline Palavras-chave & $\mathbf{0 2 / 0 5}$ a 05/05 & $\mathbf{0 6 / 0 5}$ a 12/05 & 13/05 a 19/05 & 20/05 a 31/05 \\
\hline Invasão/ões, invasores, invadido/os/a/as & - & - & - & - \\
\hline Milícia & - & - & - & - \\
\hline Facção/ões & - & - & - & - \\
\hline Aproveitador/es & - & - & - & - \\
\hline Crime, criminoso/os/a/as & - & - & - & - \\
\hline Oportunista/as & - & - & - & - \\
\hline Cobrança & & - & - & - \\
\hline Malandro/os & - & - & - & - \\
\hline Aluguel/éis & - & - & - & - \\
\hline Bandido/os/a/as/agem & - & - & - & - \\
\hline Ilegal & - & - & - & - \\
\hline Totais & & - & - & - \\
\hline
\end{tabular}

Fonte: Elaboração dos autores

A região norte registrou a terceira posição em repercussão na mídia acerca da temática da tragédia do Largo do Paissandú, bem como, sobre o debate da moradia nas manchas urbanas dos municípios, como nove matérias jornalísticas a respeito. Entretanto, destoa a cobertura entre os jornais da região, pois o jornal 10 Minutos (AM), além de ter publicado apenas uma reportagem sobre o objeto pesquisa, nesta não foram registradas nenhuma das palavras-chave selecionadas. Entretanto, o jornal Diário do Pará (PA) repercutiu o assunto em nove reportagens, porém, foram detectados apenas três registros da palavra-chave "aluguel/éis".

Os dois veículos de informação de mídia impressa nortista restringiram-se a noticiar o desastre, com poucas matérias de opinião e profundidade de análise. A mesma análise realizada em relação ao Jornal DAQUI (GO) pode perfeitamente ser aplicada ao Jornal 10 Minutos do Estado do Amazonas, pois acreditamos que, por serem impressos em formato tablóide (com menor número de páginas) e com uma proposta jornalística diversa dos grandes jornais de referência, não foi identificada qualquer palavra-chave, a partir do escaneamento realizado pelo software Search my files. 
Quadro 12: Quantidade de registros ao longo do recorte temporal

\begin{tabular}{|l|l|l|l|l|}
\hline Palavras-chave & $\begin{array}{l}\mathbf{0 2 / 0 5} \text { a } \\
\mathbf{0 5 / 0 5}\end{array}$ & $\mathbf{0 6 / 0 5}$ a 12/05 & $\mathbf{1 3 / 0 5}$ a 19/05 & $\begin{array}{l}\mathbf{2 0 / 0 5} \mathbf{a} \\
\mathbf{3 1 / 0 5}\end{array}$ \\
\hline Invasão/ões, invasores, invadido/os/a/as & 39 & 16 & 9 & - \\
\hline Milícia & 6 & 3 & 2 & - \\
\hline Facção/ões & 7 & - & 1 & - \\
\hline Aproveitador/es & - & - & - & - \\
\hline Crime, criminoso/os/a/as & 13 & 1 & 2 & - \\
\hline Oportunista/as & - & - & - & - \\
\hline Cobrança & 9 & 3 & 2 & - \\
\hline Malandro/os & - & - & - & - \\
\hline Aluguel/éis & 35 & 12 & 9 & 1 \\
\hline Bandido/os/a/as/agem & 2 & 3 & 3 & - \\
\hline Ilegal & 2 & - & 1 & - \\
\hline Totais & $\mathbf{1 1 3}$ & $\mathbf{3 8}$ & $\mathbf{2 9}$ & $\mathbf{1}$ \\
\hline
\end{tabular}

Fonte: Elaboração dos autores

Do quadro acima constatamos o efeito do transcurso do tempo sobre a repercussão da veiculação da temática atinente à questão moradia urbana e a inefetividade de política pública de moradia. Entretanto, percebemos que a acentuada diminuição no interesse do tema relativo a moradia deveu-se, sobretudo, à deflagração da greve dos caminhoneiros ${ }^{10}$ entre os dias 21 a 30 de maio de 2018, acontecimento de forte impacto nacional que provocou verdadeiro colapso na distribuição de combustíveis e alimentos ante o bloqueio de estradas, impediu o fluxo de pessoas e bens, travando por completo a economia do país em virtude da forte dependência do modal rodoviário.

No entanto, enquanto a temática do direito à moradia urbana e a ocupação de bens imóveis que não cumprem com a função social estava em evidência, ficou claro aos pesquisadores, e os números de ocorrências de palavras-chaves que imprimem uma conotação criminalizadora aos movimentos sociais de luta pela moradia, que há um conteúdo discursivo nas reportagens dos jornais brasileiros que estimula uma visão crítica da atuação dos citados movimentos, pois consiste, em linha gerais, na produção e na reprodução de uma narrativa impregnada de uma ideologia que entende o direito à propriedade como algo absoluto e intocável, em total dissonância com a ordem jurídica em vigor e,

10 Greve dos caminhoneiros: a cronologia dos 10 dias que pararam o Brasil. Disponível em:https://www.bbc.com/portuguese/brasil-44302137. Acesso em: 25 nov. 2018. 
consequentemente, é uma narrativa que promove um discurso repleto de conteúdo incriminador contra quem prioriza o direito à moradia em detrimento do exercício do direito propriedade, mesmo que o bem imóvel não esteja cumprindo nenhuma função social.

Sobre este conteúdo discursivo que promove uma criminalização dos movimentos sociais que defendem a efetividade e a garantia do direito à moradia, tal como preconizado no Art. 6o da Carta da República, faz-se necessário evidenciar em termos numéricos a quantidade de ocorrências das palavraschave selecionadas para viabilizar esta pesquisa do conteúdo existente nas reportagens e editorias dos jornais brasileiros, como abaixo:

\section{Gráfico 3: Quantidade de registros das palavras-chave}

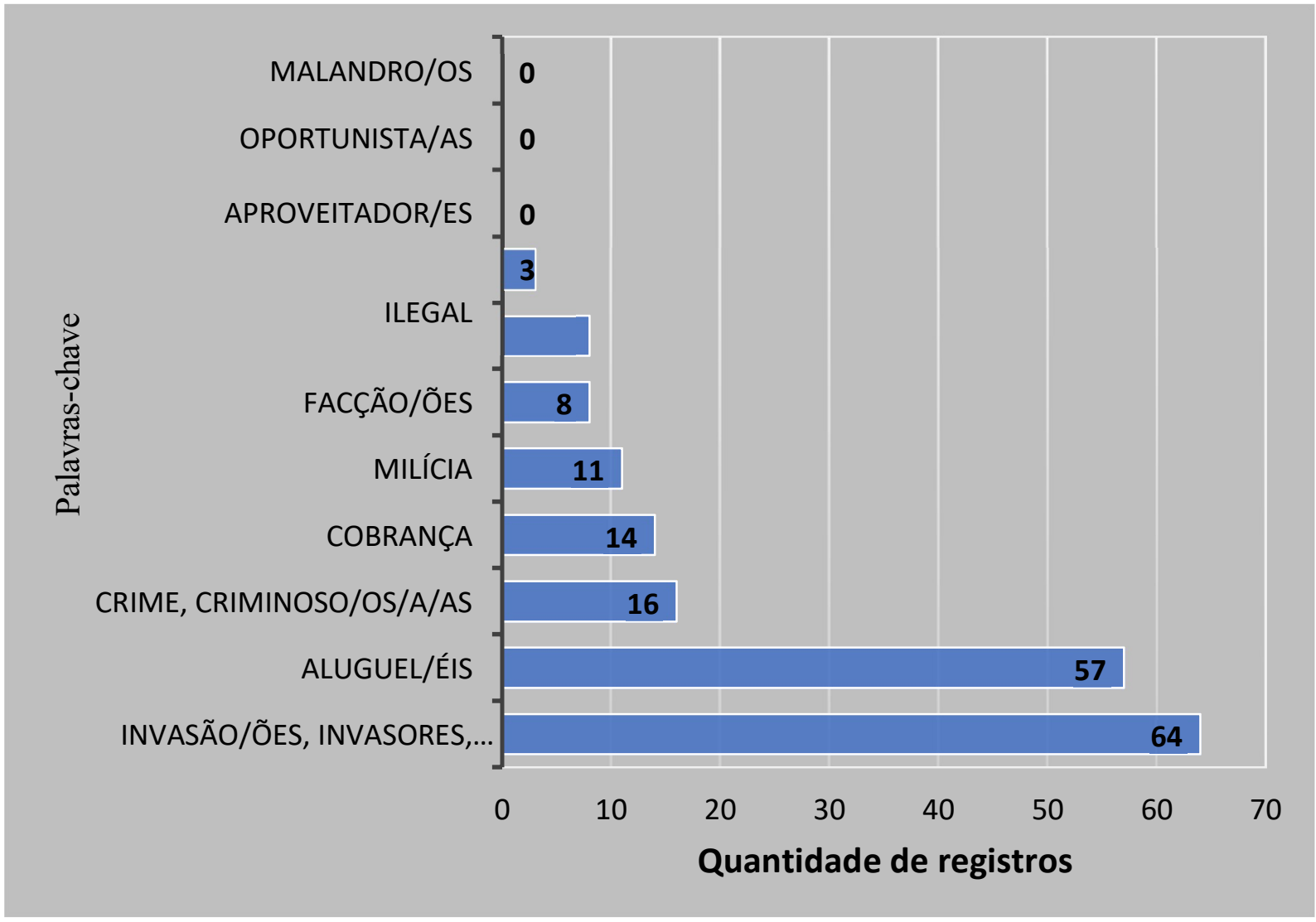

Fonte: Elaboração dos autores

Tais tabelas e gráficos permitem que os pesquisadores entendam que há um número bastante elevado de palavras-chave (chegando próxima a casa de duas centenas) que revelam a tendência de um tratamento discriminatório atribuído ao movimento social de luta pela moradia digna bem como aos cidadãos sem teto que habitam as cidades brasileiras. 


\section{CONSIDERAÇÕES FINAIS}

O desabamento do Edifício Wilton Paes de Almeida resultou na morte e no desamparo de seres humanos. Uma verdadeira tragédia de grande proporção que poderia muito bem ter sido evitada, caso as autoridades constituídas tivessem tomado todas as medidas necessárias para a implementação de uma política pública de moradia efetiva e democrática que estivesse verdadeiramente preocupada com a questão habitacional.

A partir da análise dos dados coletados, constatamos objetivamente que a cobertura dos dez maiores meios de comunicação em mídia impressa nacional, em sua maioria, posicionam-se de forma tendenciosa, buscando passar a imagem dos líderes do movimento como exploradores do sofrimento alheio, pois segundo o conteúdo discursivo expresso nas reportagens e editoriais afirmam que existe a cobrança por parte das lideranças dos movimentos sociais de taxas/alugueis, bem como, o uso de palavras como: bandidos, milícia, facção e criminosos.

No mesmo sentido, há uma explícita qualificação pejorativa dos moradores do Edifício Wilton Paes de Almeida, denominando-os de "invasores", dentre outras palavras-chave como demonstramos na pesquisa, seja por meio de quadro ou gráficos. Destarte, o tratamento incriminador atribuído aos moradores do edifício que ruiu pode ser plenamente estendido aos demais brasileiros e brasileiros que estão na mesma situação, afinal, o conteúdo discursivo incriminador contido nas reportagens e editoriais é generalista, ou seja, todos aqueles que estiverem ocupando imóveis urbanos que não estejam cumprindo com a função social para garantir o seu direito subjetivo à moradia, serão taxados de "invasores", portanto, de criminosos, de bandidos, de milicianos e de integrantes de facção ligado à atos ilícitos.

Ademais percebeu-se que foi necessária uma tragédia de tal magnitude para que os meios de comunicação brasileiros passassem a se interessar pela temática da crise habitacional do país, chamando a atenção uma série de reportagens que destacaram o problema da moradia em âmbitos locais e regionais a respeito do tema. Todavia, a repercussão do assunto sempre esteve carregada de palavras que representam uma visão discriminatória e sem solidariedade humana, bem como, uma narrativa jornalística que não está de acordo com a ordenamento jurídico nacional que deixa patente que a moradia é um direito social e, portanto, que deve ser garantida pelo Estado.

Sendo assim, a utilização da metodologia quali-quantitativa e da técnica da análise de conteúdo realizada por intermédio do software Search my files possibilitou aos pesquisadores observarem objetivamente a tendência da linha editorial dominante do jornalismo brasileiro, consistindo em um esforço nada sutil de colocar como culpados aqueles que são, em verdade, as 
maiores vítimas devido à falta de moradia. Destarte, há uma explícita tentativa de culpabilizar o movimento social de Luta por Moradia no país.

Por fim, em que pese o fato de os movimentos sociais urbanos contemporâneos traduzirem demandas de segmentos sociais de modo a organizar a luta coletiva em face de situações de exclusão ou segregação socioespacial nas cidades, fenômeno representado, em grau máximo, pelo déficit de moradias, constatamos que o tratamento dado pela mídia impressa brasileira tende a criminalizar o movimento social de luta pela moradia.

\section{REFERÊNCIAS}

10 MINUTOS, Manaus (AM): Edições 02 a 31 de maio 2018.

Associação dos Jornais do Brasil. Maiores Jornais do Brasil. Disponível em: <http://www.anj.org.br/maiores-jornais-do-brasil/>. Acesso em 15 nov. 2018.

BERGAMIN JR, Giba. Moradores de ocupação pagavam R\$ 400 de aluguel em prédio que desabou em SP. Globo (G1), São Paulo. Disponível em:<https://g1.globo.com/sp/sao-paulo/noticia/moradores-deocupacao-pagavam-r-400-de-aluguel-em-predio-que-desabou-em-sp.ghtml>. Acesso em: 21 nov. 2018.

BONDUKI, Nabil. A Reforma Urbana no Processo de Participação Popular na Constituinte. In: Constituição 20 Anos: Estado, Democracia e Participação Popular: caderno de textos. Brasília: Edições Câmara, 2009.

BRASIL. Constituição. Constituição da República Federativa do Brasil. Brasília, DF: Senado Federal, 1988.

BRASIL. Lei no 10.257, de 10 de julho de 2001. Palácio do Planalto. Disponível em:<http://www.planalto.gov.br/ccivil_03/leis/leis_2001/l10257.htm.> Acesso em: 25 jul 2018.

BRASIL. Instituto Brasileiro de Geografia e Estatística- IBGE. Censo demográfico 2010. Disponível em:<www.censo2010.ibge.gov.br.> Acesso em: 20 jul. 2018.

BRASIL. Instituto Brasileiro de Geografia e Estatística- IBGE. Aglomerados Subnormais Informações Territoriais. Disponível

em:< https://ww2.ibge.gov.br/home/presidencia/noticias/imprensa/ppts/000000069235121120113554156 
75088.pdf>. Acesso em: 20 nov. 2018.

BRASIL. Instituto Brasileiro de Geografia e Estatística- IBGE, Indicadores Sociodemográficos Prospectivos $\begin{array}{lllll}\text { para } & 0 & \text { Brasil } & \text { 1991-2030. } & \text { Disponível }\end{array}$ https://ww2.ibge.gov.br/home/estatistica/populacao/projecao_da_populacao/publicacao_UNFPA.pdf .> Acesso em 25 jul. 2018.

BRASIL. Instituto Brasileiro de Geografia e Estatística - IBGE. Tipologia Intraurbana - Espaços de diferenciação socioeconômica nas concentrações urbanas do Brasil. Disponível em:<https://censoagro2017.ibge.gov.br/agencia-noticias/2012-agencia-de-noticias/noticias/18906em-areas-urbanas-38-1-da-populacao-viviam-em-mas-condicoes-de-vida.> Acesso em 18 jul. 2018.

BRITTOS, Valério Cruz, BOLAÑO, César Ricardo Siqueira. (Org.). Rede Globo: 40 anos de poder e hegemonia. São Paulo: Paulus, 2005.

CARLOS, Ana Fani. A metrópole de São Paulo no contexto da urbanização contemporânea. ESTUDOS AVANÇADOS 23 (66), 2009. Disponível em:< http://www.scielo.br/pdf/ea/v23n66/a21v2366.pdf>. Acesso em: 20 nov. 2018.

CORREIO BRAZILIENSE, Brasília: Edições de 02 a 31 de maio 2018.

CORREIO, Salvador (BA): Edições de 02 a 31 de maio 2018.

DAQUI, Goiânia (GO): Edições de 02 a 31 de maio 2018.

DIÁRIO DO PARÁ, Belém (PA): Edições de 02 a 31 de maio 2018.

DOCOMO. A perda de um ícone da arquitetura moderna paulista: o Edifício Wilton Paes de Almeida. Disponível em:<https://www.nucleodocomomosp.com.br/noticias/a-perda-de-um-\%C3\%ADcone-daarquitetura-moderna-paulista-o-edif\%C3\%ADcio-wilton-paes-de-almeida>. Acesso em: 21 nov. 2018. 
FALCÃO, Monique. FALBO, Ricardo. Quilombo das Guerreiras e Zumbi dos Palmares: Movimentos Sociais pelo direito à moradia na cidade do Rio de Janeiro. Revista de Direito da Cidade, Rio de Janeiro,vol. 08, n.01, pp.331-360, 2016

FOLHA DE S. PAULO, São Paulo (SP): Edições de 02 a 31 de maio 2018.

FUNDAÇÃO JOÃO PINHEIRO. Déficit Habitacional no Brasil 2015. Centro de Estatística e Informações Belo Horizonte, 2015. Disponível em: <http://www.fjp.mg.gov.br/index.php/docman/direi2018/estatistica-e-informacoes/797-6-serie-estatistica-e-informacoes-deficit-habitacional-no-brasil2015/file> . Acesso em 18 jul. 2018.

GOHN, Maria da Glória. Teorias dos movimentos sociais. Paradigmas clássicos e contemporâneos. São Paulo: Loyola, 1997.

GOSS, Karine Pereira; PRUDENCIO, Kelly. O conceito de movimentos sociais revisitado. Revista Eletrônica dos Pós-Graduandos em Sociologia Política da UFSC Vol. 2, № 1 (2), janeiro-julho 2004, p. 75-91. Disponível em: < https://periodicos.ufsc.br/index.php/emtese/article/viewFile/13624/12489>

HARVEY, David. Cidades rebeldes: do direito à cidade à revolução urbana. São Paulo: Martins Fontes, 2014.

IGREJA, Rebecca . O Direito como objeto de estudo empírico: o uso de métodos qualitativos no âmbito da pesquisa empírica em Direito. In: Machado, Maíra Rocha (Org.). Pesquisar empiricamente o direito. São Paulo: Rede de Estudos Empíricos em Direito,2017.

"invasão", In: Dicionário Priberam da Língua Portuguesa [em linha], 2008-2013, disponível em:<https://dicionario.priberam.org/invas\%C3\%A3o> [consultado em 21-11-2018].

JORNAL DO COMMÉRCIO, Recife (PE): Edições 02 a 31 de maio 2018

LEFEBVRE, Henri. O Direito à Cidade. São Paulo: Centauro, 2001.

KOWARICK, Lúcio. A espoliação urbana. São Paulo: Editora Paz e Terra, 1993. 
MACHADO, Maíra Rocha (Org.). Pesquisar empiricamente o direito. São Paulo: Rede de Estudos Empíricos em Direito, 2017.

NALINI, José Renato. Direitos que a cidade esqueceu. São Paulo: Editora Revista dos Tribunais, 2012

"ocupar", in Dicionário Priberam da Língua Portuguesa [em linha], 2008-2013, https://dicionario.priberam.org/ocupar [consultado em 01-12-2018].

O GLOBO, Rio de Janeiro (RJ): Edições 02 a 31 de maio 2018.

QUEIROZ FILHO, Alfredo Pereira de. As definições de assentamentos precários e favelas e suas implicações nos dados populacionais: abordagem da análise de conteúdo. Revista Brasileira de Gestão Urbana, 2015. Disponível em: < http://www.scielo.br/pdf/urbe/2015nahead/2175-3369-urbe-21753369007003A003.pdf> Acesso em 30 nov. 2018.

SANTOS, Milton. O Espaço do Cidadão. São Paulo: EDUSP, 7ạ Edição, 2014.

SÃO PAULO. Prefeitura lança PPP para construção de 34 mil moradias na capital. Disponível em:https://www.prefeitura.sp.gov.br/cidade/secretarias/habitacao/noticias/?p=248360. Acesso em: 21 nov. 2018.

SAULE JR, Nelson; UZZO, Karina. A trajetória da reforma urbana no Brasil. In: SUGRANYES, Ana; MATHIVET, Charlotte (org.). Cidades para todos: propostas e experiências pelo direito à cidade. Santiago, Chile: $\quad 2010.25$ p. 259-270. Disponível em:<http://www.gloobal.net/iepala/gloobal/fichas/ficha. php?entidad=Textos\&id=12275\&opcion=doc umento\#s186 >. Acesso em 15 nov. 2018.

SEARCH MY FILES . Disponivel em:<https://www.techtudo.com.br/tudo-sobre/search-my-files.html.>. Acesso em 15 set. 2018.

SETO, Guilherme; GOMES, Paulo. Curto-circuito provocou incêndio em prédio que ruiu em SP, diz $\begin{array}{lllll}\text { secretário. } & \text { Folha de } & \text { Pãononível }\end{array}$ 
em:https://www1.folha.uol.com.br/cotidiano/2018/05/incendio-em-predio-que-desabou-foi-causadopor-curto-circuito-diz-secretario.shtml. Acesso em: 21 jun. 2018.

SOUSA, Jorge Pedro. Elementos de Jornalismo Impresso. Porto (Portugal): Letras Contemporâneas, 2005.

VIEIRA, Bruno Soeiro; BACELAR, Jeferson Antonio Fernandes. Direito fundamental à moradia: por um novo paradigma de requalificação do velho centro commercial de Belém (PA). In: Direito e sustentabilidade [Recurso eletrônico on-line] organização CONPEDI/UFS; Coordenadores Consuelo Yatsuda Moromizato Yoshida, Raquel Fabiana Lopes Sparemberger, Rosângela Lunardelli CavallazziFlorianópolis: CONPEDI, 2015.

Trabalho enviado em 22 de janeiro de 2019

Aceito em 03 de fevereiro de 2020 